I very much welcome this fine new text on dislocations, despite the fact that there are already perhaps half a dozen or so books on this subject. It is probably the most comprehensive of all and certainly outstandingly lucid in presentation. It will remain a main authority in the field for a long time.

S. Tolansky

\section{RUSSIAN RADIOPATHOLOGY}

\section{Studies in the Pathology of Radiation Disease}

By N. A. Krayevskii. Translated by A. Lieberman. English translation edited by Hermann Lisco and Malcolm Walker. Pp. xv + 219. (London and New York: Pergamon Press, 1965.) 100s. net.

$\mathrm{A}^{\mathrm{T}}$ first sight it seems pointless to translate a book on the pathology of radiation injury written in 1957 and unamended since. The justification might be that basic descriptions of morbid histology have a permanent value regardless of time, or that there are important Russian data hitherto unknown to the West.

Unhappily in this case neither claim can be upheld. The main bulk of Studies in the Pathology of Radiation Disease is an account, tissue by tissue, of the gross and microscopic changes induced by radiation (mostly to the whole body) in dogs, cats and rats. Both acute and chronic radiation effects have been studied using either external irradiation or internally administered isotopes. Many of the descriptions are careful and detailed but the terms used are sometimes vague or undefined. For example, what precisely is meant by "disturbed haemopoiesis . . . in the form of progressive pernicious anaemia"? and, referring to recovery from radiation, "a mobilisation of internal resources occurs which is mediated particularly through the nervous system. Following I. P. Pavlov, we may look on this process as a physiological counter-measure to the disease" ?

An extraordinary omission is of any reference to blood platelets. In page after page there are descriptions of haemorrhages in various organs and all are attributed entirely to blood-vessel damage. In fact, the words 'platelet' and 'thrombocytopaenia' do not occur throughout the whole text. In compensation, perhaps, one of the longer chapters (by Prof. Portugalov) concerns the nervous system. His final comment, however, is on the 'slightness' of the radiation effects, and one wonders whether this accords with the general Russian view.

The illustrations are of mixed quality and suffer from a complete absence in the captions of any reference to staining technique or magnification.

It is in the final chapter, "Conclusions", that the lack of modernity is most evident. What is the use of quoting old speculations on radiosensitivity in different phases of cell cycle when the subject has since been studied. experimentally? And the references to human radiopathology are inevitably meagre if all that has happened since 1957 is left out. Perhaps a better book could have been written in 1965; certainly this edition cennot be recommended.

H. E. M. KAY

\section{THE GRASSHOPPERS AND LOCUSTS OF AFRICA}

\section{The African Genera of Acridoidea}

By V. M. Dirsh. Pp. xiii + 579. (London : Cambridge University Press, 1965. Published for the Anti-Locust Research Centre.) 200s. net; 37.50 dollars.

$\mathrm{W}$ HAT is the difference between a grasshopper and a locust ? The answer will not be found in The African Genera of Acridoidea; the reader is expected to know. Indeed, the answer has nothing to do with taxonomy, which is the subject of this book; the distinction is one of ecology and behaviour. In passing, it may be noted that in America they are all called 'grasshoppers': the name 'locust' is reserved for the cicadas. Within the British Commonwealth the grasshoppers follow a more or less 'solitary' existence ; they tend to remain throughout their lives in one locality. But certain species of Acridoidea change their habits from time to time: for long periods they may live solitary lives like the other grasshoppers; but when their numbers increase they reveal a capacity to gather together in great companies or swarms. In this 'gregarious' state they will undertake migrations, the larval stages or 'hoppers' on foot, the winged adults in the air. It is those species with the tendency to enter on such migrations that are called locusts. In certain of these species the gregarious or migratory 'phase' is strikingly different from the solitary nonmigrating phase, not only in behaviour but also in coloration, morphology and physiology.

In elementary entomology those Orthoptera with enlarged hind-legs adapted for leaping (the 'Saltatoria' of Latreille) fall into three groups: the long-horned grasshoppers (Tettigoniidae), the short-horned grasshoppers (Acrididae), and the crickets (Gryllidae). Here we are concerned only with the short-horned grasshoppers which are now classified as a superfamily, the Acridoidea, of which the family Acrididae is by far the largest and is indeed subdivided into a great number of subfamilies of which no less than sixteen are represented in Dr. Dirsh's book on the African genera. The vast majority of the species included in these genera would be called 'grasshoppers'. There are only some half-dozen species belonging to the genera Locusta and Locustana (of the subfamily Acridinae), and Anacridium, Nomadacris, Schistocerca (of the subfamily Cyrtacanthacridinae), which are recognized as gregarious and migratory locusts.

At the present time, most of the major species of plague locusts in Africa and Asia are in a temporary state of recession. But meanwhile the cultivator is becoming increasingly concerned about the grasshoppers, which in the past had been considered of small importance. When large-seale mechanized erop production was developed in the Anglo-Egyptian Sudan in the 1940's, about a score of local species of grasshoppers became quite serious endemic pests. Species which had normally subsisted on wild grasses found cultivated sorghum an attractive diet, and the cultivation of the soil facilitated their breeding. As mechanized cultivation spreads throughout Africa, the same problems are certain to arise elsewhere. Hence the interest in building up a systematic background to help the entomologist to recognize his potential pests. It may well be that on closer acquaintance some of these grasshopper species will be found to possess latent powers of swarming and migration which will entitle them some day to be called locusts.

The African genera of locusts and grasshoppers as described in this book number about six hundred and fifty and embrace nearly two thousand species. Many of them have beon inadequately described in earlier publications. Dr. Dirsh has been faced with a most formidable task in revising, checking and collating all the information (up to 1958) available about these insects and presenting it in a compact but comprehensive form. He has accomplished this task with complete success. Some four hundred and fifty carefully drawn illustrations supplement the descriptions of the genera. There are keys and brief statements of diagnostic characters for families, subfamilies and genera, and a list of the African species in each genus. Geographical distribution is given in general terms. This book, like its companion volume already well known to workers in this field, H. B. Johnston's Annotated Catalogue of African Grasshoppers, is published on behalf of the Anti-Locust Research Centre, London. It will be a standard work for many years to come.

\section{B. WIGGLESWORTH}

